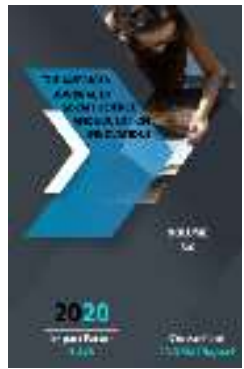

Journal Website: http://usajournalshub.c om/index,php/tajssei

Copyright: Original content from this work may be used under the terms of the creative commons attributes 4.0 licence.

\section{The Importance Of Using "Temur Tuzuks" To Improve The Activities Of Military Workers}

\author{
Jahongir Shuhratovich Dadadjanov \\ Senior Lecturer, Academy Of The Armed Forces Of The Republic Of Uzbekistan \\ Abdumannop Inamjonovich Turgunov \\ Lecturer, Academy Of The Armed Forces Of The Republic Of Uzbekistan
}

\title{
ABSTRACT
}

The article analyzes the role of Amir Temur in the history of Central Asia, his contribution to world civilization, the content of the conceptual ideas put forward in the work "Temur tuzuklari" (Regulations of Temur). The great state policy of Amir Temur to ensure the stability of the state is analyzed on the basis of sources, the creative work carried out by Temur and the reforms in the field of public administration are studied. Amir Temur's attitude to the servicemen and the various material and spiritual incentives he showed them was also shown.

\section{KEYWORDS}

Regulations, material and spiritual heritage, attitude to the military, public administration, renaissance.

\section{INTRODUCTION}

It is known from the history of mankind that at certain periods in the life of a society such individuals are born who, while doing things capable of changing the history of an entire nation, bring an entire society out of inevitable decline and leave a huge material and spiritual legacy in world civilization. Future generations, on the other hand, will realize how great this great contribution of their past ancestors to development is and how incapable it is to measure its weight, and they will feel a sense of pride with their ancestors as they always bow before their memory. Amir Temur ibn Amir Taragay ibn Amir Barkul is one of the great figures of the past, a symbol of justice and power, who 
completely changed the development of mankind and had a profound impact on world civilization.

Amir Temur was recognized by many historians, political scientists, philosophers as the founder of the second Renaissance in the history of Central Asia, and was recognized as the ruler of political stability in Central Asia in the late fourteenth and early fifteenth centuries. He has also made a huge contribution to the development of social and cultural spheres. After all, the development of trade at that time, reforms in agricultural development, the restoration of irrigation facilities, the construction of canals undoubtedly had a positive impact on the infrastructure of the region and had a positive impact on the lives of different segments of the population.

\section{MATERIALS AND METHODS}

The content analysis of the sources shows that we can find valuable historical-factual opinions on the policy of Amir Temur to ensure the stability of the state. For example, "After re-occupying Chach, he established his rule in the whole of Movarounnahr. It is noted that it created the opportunity to irrigate the lands and to implement the reforms such as the development of protected lands, the unprecedented harvest of grain, the establishment of gardens and the digging of canals" [1]. Another historical source states that Amir Temur "made various donations, gave class alms, and gave a lot of soup to the poor and needy" [2], which shows that Amir Temur was not only a great ruler, but also an exemplary political figure in generosity.

\section{RESULTS AND DISCUSSION}

The role of the military is important in ensuring the stability of society, as evidenced by the high level of professional training. It is no secret that they are selfless in ensuring the peace, tranquility and the security of the country. In this regard, Professor R. Samarov, who has conducted a lot of research in the military field, said: Determining the genesis and evolutionary stages of military activity in the in-depth study of the factors that motivate people to engage in military activity, for this purpose, the study of the creative patterns of our ancestors can give effective results. Such works are an integral part of the national values and ideology of our people, and are one of the important educational factors in understanding the spirit of self-knowledge and patriotism. The ideas put forward in these works show that the themes of sincerity in human relations, human dignity in profession, everyone is responsible for the fate of the Motherland are the motives of their creativity [3], and one of such works is undoubtedly "Temur tuzuklari" (Regulations of Temur).

It is known that "Temur tuzuklari" is a comprehensive anthological-unique work, written in a unique way, and we found it necessary to interpret the attitude of Amir Temur to the servicemen reflected in this work on the basis of documentary methods. For example, the book "Temur tuzuklari" shows that he ruled the state on the basis of twelve rules. These rules state: "He ruled the country according to religious norms, divided the society into twelve classes, held consultations and councils on important issues, listened to the advice of certain officials in public affairs, ruled in accordance with the laws established by the state, and paid great attention to military incentives that he carried out compassionate and charitable deeds in strict accordance with the principles of justice and fairness in governing the state, that he supported the honorable people of his time, that he acted with determination in carrying out any action, and he was tolerant of 
all nations. He did good deeds, was generous and kind to all his relatives, and treated all the soldiers with respect and dignity [4]. These rules remain relevant not only in their time, but also in the context of the pandemic that prevails around the world today.

Indeed, the state must carry out its activities in the economic, social, political, cultural and similar spheres, as well as in the military or defense spheres, because this aspect is very important for the stability, existence and further development of the state. Therefore, in two of the twelve rules mentioned above, Amir Temur's attitude towards the military was clearly expressed. In particular, in the fifth statute: "I pleased my commanders and soldiers with ranks and titles, gold and silver. I gave them a (worthy) place in the feasts, so they sacrificed their lives in battles. "I did not spare dirhams and dinars from them", he said. As a result, he wrote: He says that I have loaded myself with their labor and hard work to make their work easier and brought them up. He writes that he created the necessary conditions for the military and treated them with due care, as a result of which the Emirs, in alliance with the heroes, relied on their courage and took the throne of twenty-seven kings by the sword [5]. Indeed, the study of this work from a retrospective perspective must take into account, firstly, the ideological view prevailing in the Middle Ages due to the conditions of the time, and secondly, the functional significance of the role of the army as a social institution.

We can also see that the twelfth constitution also reflected Amir Temur's attitude towards the military, that is, soldiers serving in the army. In particular, "in spite of their friendship and enmity, I respected the soldiers everywhere because they sell their souls, which are eternal cloth, for the goods of the mortal world. They throw themselves into the arena, into destruction, and sacrifice their lives.

Even if someone from the enemy's army faithfully served his valine and raised his sword against me in the days of war, I showed mercy to such a person. When he came to me (seeking refuge), I appreciated him, gained his trust, and believed that he would serve me faithfully and truthfully..." [6] he writes. Thus, Amir Temur highly valued the role and place of the common navkar (soldier) in the army, which is one of the main sources for studying, researching and analyzing the ideas of military patriotism in today's youth. Mankind has been striving to understand himself and the world around him throughout his conscious life. But his early knowledge was a collection of fragmentary, unconnected knowledge. Gradually, man began to organize, systematize, classify the knowledge accumulated by himself and the intellectual forces around him. If we summarize all this knowledge into a single system, just as the system of knowledge about the existence of mankind came into being [7], if we read the "Regulations of Timur" diligently, we will see to what extent he treated the abovementioned representatives of the military. Whichever country I conquered, I revered the dignitaries of that land, paid homage and respect to the clergy, scholars, and musicians, gave them duties, and set their salaries; I saw the elders of that region as my brothers, and the youth and children as my own children. He writes that the door was open for the armies of these countries [8]. It is known from historical sources that while most of the invaders treated the defeated side with cruelty and oppression, it can be seen that Amir Temur, unlike other invaders, followed the principle of "power and justice".

\section{CONCLUSIONS}


In general, first of all, Amir Temur ruled the state not only as a head of state, but also as a people's, nationalist leader, setting up the advanced military activities of his time. He also achieved great success in his time, creating a superior form of the system of views on military tactics and strategy.

Second, Amir Temur had the ability to hear and accept the opinions of others. This is determined by the fact that each nation has a strong ability to know its nature and psyche.

Thirdly, it is clear that Amir Temur in his sociopolitical views, rather than dreaming of a perfect society, realizes it and takes responsibility for it.

Fourth, "Temur tuzuklari" is an important source in the patriotic education of future servicemen; the promotion of theoretical and conceptual ideas put forward among future officers serves to improve the performance of servicemen.

\section{REFERENCES}

1. Marcel B. I am Temur, master of the universe. / Translators: F.Ruziev, F.Tilovatov. - Tashkent: Yangi asr avlodi, 2016. - pp. 72-73.

2. Ayazi Mirza Muhammad Khaydar. History Rashidi. - Tashkent: Uzbekistan, 2011. - p. 111.

3. Samarov R. Defensive activity: theoretical approaches. Monograph. - Tashkent: Sparks of Literature, 2017. - pp. 150-151.

4. Temur tuzuklari. - Tashkent: Shodlik, 2018. - pp. 70-75.

5. Temur tuzuklari. - Tashkent: Shodlik, 2018. - pp. 70-71.

6. Temur tuzuklari. - Tashkent: Shodlik, 2018. - pp. 74-75.

7. Turaev B. Being: essence, forms, feature. Tashkent: Philosophy and Law, 2011. -p.5.
8. "Temur tuzuklari". Tashkent, 1991. - pp. 94-95.

9. Karimov N.R. Some researches on Abu Isa Tirmidhi in European countries. International Journal of Current Research, 10/12, 2018. pp. 76170-76173 